\title{
Organochlorinated pesticide multiresidues in surface sediments from Beijing Guanting reservoir
}

\author{
Nandong Xue, Daren Zhang, Xiaobai Xu* \\ Research Center for Eco-Environmental Sciences, Chinese Academy of Sciences, State Key Laboratory of Environmental Chemistry and \\ Ecotoxicology, 18 Shuangqing Road, Beijing 100085, China
}

\section{A R T I C L E I N F O}

Article history:

Received 24 January 2005

Received in revised form

16 May 2005

Accepted 3 July 2005

Available online 20 December 2005

Keywords:

Guanting reservoir

Surface sediment

Organochlorine pesticides (OCPs)

\begin{abstract}
A B S T R A C T
For the analysis of organochlorine pesticides (OCPs) in sediments and water, a multiresidue analysis method based on gas chromatography with electron capture detection (GC/ECD) was developed. Solid-phase extraction (SPE) using Oasis ${ }^{\circledR}$ HLB cartridges was also applied in sample extraction. Mean recoveries were satisfactory with $72-103 \%$ and $71-103 \%$ for water and sediment, respectively. Twenty-one OCPs were analyzed in water and surface sediment samples from Beijing Guanting reservoir. Total concentrations of 21 OCPs were 16.7-791 ng/l (mean 234ng/l), 275-1600 ng/l (mean 644ng/l), 5250-33,400 ng/kg (mean $13,000 \mathrm{ng} / \mathrm{kg}$ ) in surface water, pore water and sediment (dry weight), respectively. $\mathrm{P}, p^{\prime}$ DDE, $\delta$ - $\mathrm{HCH}$, aldrin, $\gamma-\mathrm{HCH}$ and $\beta-\mathrm{HCH}$ are the most abundant compounds in water while $p$, $p^{\prime}$-DDE, o, $p^{\prime}$-DDT, $\beta$-HCH, $\delta$-HCH, $p, p^{\prime}$-DDT and aldrin accounted for about $85 \%$ of total 21 OCPs in sediment in Beijing Guanting reservoir. Concentrations of OCPs were high both in water and sediment samples in Beijing Guanting reservoir for municipal water supply. The data provides information on the levels and sources of OCPs in Guanting reservoir. The study indicated that measures should be taken to decrease OCPs residues in order to improve the quality of municipal water supply in Beijing.
\end{abstract}

(c) 2005 Elsevier Ltd. All rights reserved.

\section{Introduction}

Guanting Reservoir located northwest of Beijing (approximately $90 \mathrm{~km}$ northwest) was built in 1952, with a storage capacity of 410 million $\mathrm{m}^{3}$ and is one of two main water resources $(92.98 \%$ of the total reservoir storage capacity in Beijing) for agriculture, industry and potable uses of Beijing. Since Guanting reservoir has suffered from extensive pollution over the last years (particularly in 1980s) due to runoff from non-point sources, direct dumping of wastes, unmanaged fishing, unrestricted shipping, mineral exploitation, and pollutants carried by rivers (Wang et al., 2003; Zhang et al., 2004). Water from this reservoir was not used as potable water since 1997.
Pesticides are important class of pollutants in Guanting reservoir. Not only can the pesticides be bio-concentrated through biogeochemical processes, but also often scavenged from the water through sorption onto suspended material, and then they get deposited to become a part of the bottom substrate. The sediment component of aquatic ecosystems can deposit pesticides. Consequently, bottom sediments often become storage of pesticides in the environment (Khan, 1977; Chau and Afgan, 1982). Different pesticides pose varying degrees and types of risk to water quality. Some pesticides (such as parathion and other organophosphate compounds) are highly soluble in water and relatively short-lived in the environment and may cause short-term problems when present at high concentrations. Some organochlorine

*Corresponding author. Tel.: +8610 62919177; fax: +861062923563.

E-mail address: xuxb@public.bta.net.cn (X. Xu).

0043-1354/\$ - see front matter (c) 2005 Elsevier Ltd. All rights reserved. doi:10.1016/j.watres.2005.07.044 
pesticides (OCPs) such as DDTs, hexachlorocyclohexanes (HCHs), chlordanes (CHLs), hexachlorobenzene (HCB), aldrin, dieldrin, endrin, endrin aldehyde, heptachlor, heptachlor epoxide (HEPO), endosulfan I, endosulfan II, and endosulfan sulfate are only slightly soluble in water and highly resistant to degradation by biological, photochemical or chemical means, and their residues may persist in soil, aquatic sediment, and biomagnify in the food web (Tanabe et al., 1997). Over the past 30 years, the occurrence of OCPs in the environment is of great concern due to their persistent (Doong et al., 2002a) and long-range transportable nature (Fillmann et al., 2002) as well as toxic biological effects (Tanabe et al., 1994; Wania and Mackay, 1996). Studies have suggested that OCPs may affect the normal function of the endocrine system of humans and wildlife (Colborn and Smolen, 1996; Xue et al., 2005). Thus, OCPs in aqueous environment have attracted extensively interests from environmental scientists and public.

Despite the ban and restriction on the usage of some OCPs in developed countries during the 1970s and 1980s, some developing countries are still using them for agricultural and public purposes because of the low cost and versatility in controlling various insects (Iwata et al., 1994; Tanabe et al., 1994; Monirith et al., 2003). In fact OCPs, in some cases, are still used or they are present as persistent residues of previous uses. Some surveys of OCPs contamination have been reported in coastal and estuarine sediments collected from Asian countries such as Vietnam, Turkey, Korea and China (Nhan et al., 1999; Bakan and Ariman, 2004; Khim et al., 1999; Doong et al., 2002a,b; Hong et al., 1999; Zhang et al., 2004) indicating the presence of significant source of OCPs in this region. Several studies have reported the presence of elevated levels of OCPs, such as DDTs and HCHs, in seawater and sediments in China (e.g. Zhou et al., 2001). However, most studies examined OCPs levels in waters, sediments from the marine environment, and little information is available on OCPs contamination in freshwater samples.

The tributaries of Guanting reservoir flow through agricultural area where agrochemicals are used intensively to improve crop yields. OCPs were used heavily in these areas from the late 1940s through 1983, when they were phased out, and ultimately, some of them, banned. Although some studies have assessed the environmental quality of Guanting reservoir, data on OCP residues in surface sediments are very scarce and focus mainly on HCHs and DDTs (e.g. Wang et al., 2003). Previous studies suggested that the sediment in the reservoir was the main pollution sources of OCPs (Wang et al., 2003). Hence, comprehensive studies on organochlorine residues in sediments are need to understand the status of contamination in the Guanting reservoir.

This study focuses on the composition, distribution and characterization of 21 OCPs in surface water, pore water and surface sediments from Beijing Guanting reservoir and focuses on assess in the status of OCPs contamination in the reservoir. The data would be useful to local government to remediate the contaminated water body in order to utilize the potential municipal water supply.

\section{Materials and methods}

\subsection{Study area and sampling locations}

The locations of the sampling sites are shown in Fig. 1. The sites were chosen based on hotspots of pollution around Guanting reservoir such as industrial region, domestic wastewater discharge areas or entrances of rivers. Throughout the survey a global positioning system (GPS) was used to locate the sampling locations. The top sediment samples (a mixture of sediment from the upper $10 \mathrm{~cm}$ ) were collected by a grab sampler (Wildlife supply company, SAGINAW, Michigan, USA) in more than seven sampling sites. Samples were homogenized on site in clean glass containers. All samples were immediately sealed and stored at $-4^{\circ} \mathrm{C}$ in pre-cleaned glass jars until analysis. Samples were collected in September and November 2003, June and August 2004.

Surface water samples were collected in the same sites. Samples were taken using pre-cleaned glass bottles held in a

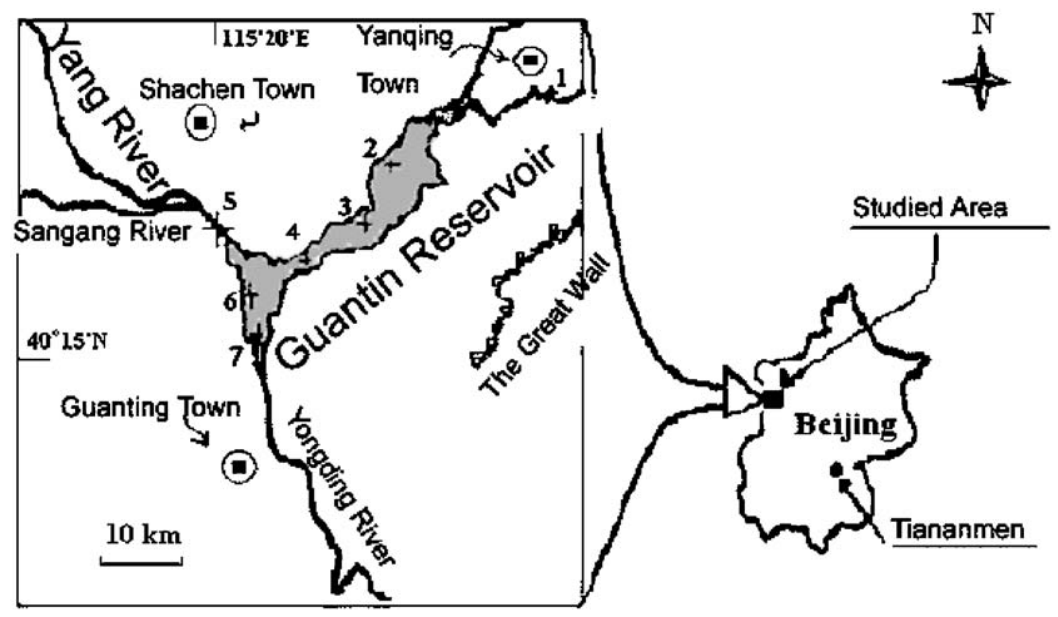

Fig. 1 - Sampling sites in Guanting reservoir and its geographical location (1-7 denote seven sampling sites in Beijing Guanting reservoir). 
weighted stainless-steel frame fitted with a spring-loaded polytetrafluoroethylene (PTFE) stopper with a subsurface trigger to avoid sampling the surface micro-layer. Aliquots of the sample (1.0l) were added with internal standard (IS) and then filtered under vacuum to remove suspended particulate matter (SPM) after returning to the laboratory within 1 or 2 days.

\subsection{Chemicals and materials}

Chromatography grade acetonitrile (ACN) and methanol (TianJing chemical plant, China), residue grade $n$-hexane, acetone, dichloromethane (DCM) and ethyl acetate (Merck, Darmstadt, Germany) were used for sample processing and extraction. Anhydrous sodium sulfate was supplied by Liu-Li chemical plant (Beijing, China) and treated at $140^{\circ} \mathrm{C}$ for $24 \mathrm{~h}$ before using. Deionized water was purified with an ultra-pure water system (Beijing Li-Yuan electronic Ltd., China). OCPs ( $p$, $p^{\prime}$-DDE; $p, p^{\prime}$-DDD; $p, p^{\prime}$-DDT; o, $p^{\prime}$-DDT; sum of $\alpha$-, $\beta$-, $\gamma$ - and $\delta$ $\mathrm{HCH}$; HCB; heptachlor; HEPO; $\alpha$-chlordane; $\gamma$-chlordane; aldrin; endosulfan I, II; endosulfan sulfate; endrin aldehyde; endrin; diedrin; methoxychlor) and IS (2,4,5,6-tetrachloro-mxylene) used in this study from Dr. Ehenstorfer (Augsburg, Germany) were purchased from J \& K Chemical Ltd. (Table 1). All of them were neat compounds (purity $>95 \%$ ). Standard solutions of pesticides were prepared in acetone or alcohol and stored in freezer at $-20^{\circ} \mathrm{C}$. The stock standard solution of each pesticide was prepared at $2 \mathrm{mg} / \mathrm{l}$. Intermediate standard solutions were prepared by dilution in acetone for GC analyses in the range $0.01-1.0 \mathrm{ng} / \mathrm{l}$. Florisil (60-100 mesh) from Supelco Inc. (Bellefonte, PA, USA) was used as sorbents in the clean-up columns. Florisil was activated at $130^{\circ} \mathrm{C}$ for $12 \mathrm{~h}$ and partially deactivated with $0.5 \%$ water prior to experiment. The columns were protected against water by adding a 1-cm layer of anhydrous sodium sulfate (Liu-Li Chemical Plant, Beijing) on top of the sorbent. The Oasis ${ }^{\circledR}$ HLB cartridge $\left(6 \mathrm{~cm}^{3}, 500 \mathrm{mg}\right)$ was purchased from Waters Corp. (Milford, MA, USA) and Visiprep ${ }^{\text {TM }}$-DL SPE Vacuum Manifold with disposable flow control valve liners, a solid-phase extraction (SPE) system, from Supelco Inc. (Bellefonte, PA, USA).

All glasswares were treated with sulfochromic mixture at first, and then washed with different solvents in the order of water, acetone and $n$-hexane prior to use.

\subsection{Analytical procedures}

Water samples collected from Guanting reservoir were prefiltered using $0.45 \mu \mathrm{m}$ PTFE fiber-glass filters (Millipore, Bedford, MA, USA) to eliminate particulate matter. Up to 11 of water samples were extracted by SPE following the method from Nogueira et al. (2004). An IS was added to each water sample $\left(0.05 \mu \mathrm{g}\right.$ IS per liter of water sample). Each of Oasis ${ }^{\circledR}$ HLB cartridges was conditioned with $5 \mathrm{ml}$ of methanol/ ACN

Table 1 - Average recoveries and relative standard deviations (RSD\%) for 21 organochlorine pesticides (OCPs) and in water and sediment fortified at $0.05,0.1,0.5 \mu \mathrm{g} / \mathrm{l}$ in water and $0.5,5.0,50 \mu \mathrm{g} / \mathrm{kg}$ in sediment

\begin{tabular}{|c|c|c|c|c|}
\hline \multirow[t]{2}{*}{ IS and OCPs } & \multicolumn{2}{|c|}{$\begin{array}{l}\text { Average recoveries (\%) } \pm \mathrm{RSD}(\%) \text { in } \\
\text { water }\end{array}$} & \multicolumn{2}{|c|}{$\begin{array}{l}\text { Average recoveries (\%) } \pm \text { RSD (\%) in } \\
\text { sediment }\end{array}$} \\
\hline & Recoveries (\%) & RSD (\%) & Recoveries (\%) & RSD (\%) \\
\hline IS $^{\mathrm{a}}$ & 97 & \pm 2 & 92 & \pm 5 \\
\hline$\alpha-\mathrm{HCH}$ & 87 & \pm 4 & 84 & \pm 6 \\
\hline $\mathrm{HCB}^{\mathrm{b}}$ & 90 & \pm 3 & 95 & \pm 5 \\
\hline$\beta-\mathrm{HCH}$ & 78 & \pm 4 & 73 & \pm 7 \\
\hline$\gamma-\mathrm{HCH}$ & 99 & \pm 6 & 93 & \pm 5 \\
\hline$\delta$ - $\mathrm{HCH}$ & 77 & \pm 7 & 81 & \pm 5 \\
\hline Heptachlor & 96 & \pm 7 & 93 & \pm 5 \\
\hline Aldrin & 101 & \pm 3 & 93 & \pm 7 \\
\hline Heptachlor epoxide & 99 & \pm 5 & 95 & \pm 7 \\
\hline$\gamma$-Chlordane & 90 & \pm 6 & 90 & \pm 8 \\
\hline Endosulfan I & 92 & \pm 5 & 90 & \pm 4 \\
\hline$\alpha$-Chlordane & 93 & \pm 6 & 87 & \pm 7 \\
\hline Dieldrin & 90 & \pm 5 & 85 & \pm 4 \\
\hline$P, p^{\prime}-\mathrm{DDE}$ & 96 & \pm 3 & 98 & \pm 5 \\
\hline Endrin & 97 & \pm 7 & 103 & \pm 5 \\
\hline Endosulfan II & 103 & \pm 6 & 97 & \pm 6 \\
\hline$p, p^{\prime}-\mathrm{DDD}$ & 89 & \pm 5 & 84 & \pm 4 \\
\hline$o, p^{\prime}$-DDT & 73 & \pm 7 & 73 & \pm 7 \\
\hline Endrin aldehyde & 89 & \pm 4 & 98 & \pm 6 \\
\hline Endosulfan sulfate & 72 & \pm 6 & 75 & \pm 8 \\
\hline$p, p^{\prime}-\mathrm{DDT}$ & 73 & \pm 7 & 71 & \pm 7 \\
\hline Methoxychlor & 84 & \pm 5 & 85 & \pm 8 \\
\hline
\end{tabular}

a IS stands for internal standard.

${ }^{\mathrm{b}}$ HCB stands for hexachlorobenzene. 
(50/50, v/v), $5 \mathrm{ml}$ of methanol and $5 \mathrm{ml}$ of ultra-pure water and slowly aspirated $(-0.2 \mathrm{bar})$. Water samples were passed through the cartridges at a flow rate of $4 \mathrm{ml} / \mathrm{min}$ under vacuum $(-0.3$ bar). The column was wash with $2 \times 5 \mathrm{ml}$ of ultra-pure water, followed by vacuum dry for $2 \mathrm{~min}$. Subsequently, the elution took place with $3 \times 4 \mathrm{ml}$ of methanol/ACN $(50 / 50, v / v)$. After water being removed from the extracts by anhydrous $\mathrm{Na}_{2} \mathrm{SO}_{4}$, the extract was reduced in volume to dryness under a gentle stream of nitrogen blow-down in a water bath. The dry residues obtained were re-dissolved in $0.5 \mathrm{ml}$ of acetone for GC determination. For blank assays the same procedure as above was performed using water samples with an IS spiked.

After returning the laboratory, routine wet sediment sample analyses were done as follows: the water content was determined by drying of about $20 \mathrm{~g}$ of wet sediments for $12 \mathrm{~h}$ (or to constant weight) at $105^{\circ} \mathrm{C}$. The dried sediment was heated at $550^{\circ} \mathrm{C}$ for $1 \mathrm{~h}$ in order to determine the organic matter (Golterman et al., 1983; Hakanson and Jansson, 1983). Silt and clay analyses of sediment samples were done by pipette analyses (Robert, 1971). pH values were determined by a $\mathrm{pH}$ meter (type pHs-2, Shanghai 2nd Analytical Instrument Factory, China). Sediment samples for OCPs analyses were centrifuged (4000 rpm, Q/ 1BL001-94, Beijing Centrifuge Instrument Factory, China) at $4{ }^{\circ} \mathrm{C}$ to obtain pore water in sediment. After being prefiltered using $0.45 \mu \mathrm{m}$ PTFE fiber-glass filters, the pore water $(300 \mathrm{ml})$ was extracted and analyzed using the same procedure as described for water samples. Twenty grams (wet weight) of the centrifuged sediments (the wet-weight ratios of the sediments have been determined and spiked with IS to quantify the overall recovery of the procedures) was weighted into a glass vial and sonicated for 30 min with $2 \times 40 \mathrm{ml}$ of methanol/ ACN (50/50, v/v) in an ultrasonic bath (Institute of acoustics, CAS, China). Extracts were transferred into glass flasks by careful decantation. Mercury treatment was employed to remove sulfur. The extracts were evaporated to about $25 \mathrm{ml}$ under vacuum with a rotavapor (Büchi 461, Flawil, Switzerland) in a water bath (about $80^{\circ} \mathrm{C}$ ). The concentrated extracts were re-extracted with hexane-ether $(6: 94,15: 85,50: 50$, v:v) three times, with $10 \mathrm{ml}$ quantities each time. The organic phase was evaporated to near dryness. The residues were cleaned up though a Florisil $(5 \mathrm{~g})$ column $(8 \mathrm{~mm}$ i.d. $\times 350 \mathrm{~mm})$. Anhydrous sodium sulfate $(2 \mathrm{~cm})$ was added to the top of the column in order to remove water. The column was then eluted first with $4 \mathrm{ml}$ of $\mathrm{DCM} / \mathrm{n}$-hexane $(20 / 80, \mathrm{v} / \mathrm{v})$ and the solution discarded. Further $25 \mathrm{ml}$ of DCM/n-hexane (20/80, v/ v) was subsequently used to elute. After collection, the eluate was evaporated nearly to dryness under a nitrogen flow. Subsequently, the sample was dissolved in $1 \mathrm{ml}$ of acetone for GC determination.

Determination was done by a GC system with a micro-cell electron capture detector ( $\mu$-ECD) and split/splitless injector (Agilent Series 6890), equipped with ChemStation Software. A fused silica capillary column (HP-5, $30 \mathrm{~m} \times 0.25 \mathrm{~mm}$ i.d., and $0.25 \mu \mathrm{m}$ film thickness) was used. The oven temperature has been programmed as follows: $80^{\circ} \mathrm{C}$ for $1 \mathrm{~min}$, ramp at $10^{\circ} \mathrm{C}$ min to $150^{\circ} \mathrm{C}$ held for $2 \mathrm{~min}$, to $180^{\circ} \mathrm{C}$ ramped at $2^{\circ} \mathrm{C} /$ $\mathrm{min}$, hold for $1 \mathrm{~min}$ and then rise to $250^{\circ} \mathrm{C}$ at a rate of $5^{\circ} \mathrm{C} / \mathrm{min}$ and hold for $1 \mathrm{~min}$. The final isotherm has been of $290^{\circ} \mathrm{C}$ at a rate of $8^{\circ} \mathrm{C} / \mathrm{min}$, hold for $5 \mathrm{~min}$, with a total run of $50 \mathrm{~min}$. The carrier gas was nitrogen, with a flow of $0.8 \mathrm{ml} / \mathrm{min}\left(160^{\circ} \mathrm{C}\right)$ and a column head pressure of $1.02 \mathrm{~atm}$. A split/splitless injector with a $2 \mathrm{~mm}$ i.d. glass-liner was used in the splitless mode for $1 \mathrm{~min}$. Injector temperature was $230^{\circ} \mathrm{C}$ and split flow was $24 \mathrm{ml} / \mathrm{min}$ until the end of analysis; the injection volume was of $1 \mu$ l. The electron capture detector temperature was kept at $310^{\circ} \mathrm{C}$ and nitrogen was used as the make-up gas with a flow of $60 \mathrm{ml} / \mathrm{min}$.

\subsection{Identification and quantification}

Before analysis, relevant standards were run to check column performance, peak height, resolution, and the limits of detection (LOD). With each set of samples analyzed, a solvent blank, a standard mixture of OCPs, and a procedural blank with IS spiked were run in sequence to check for contamination, peak identification and quantification. None of the target compounds were detected in the procedural blanks for water and sediment. Spiked water and sediment samples $(0.1 \mu \mathrm{g} / \mathrm{l}$ of each target compound) were determined with good precision and high recoveries. The chromatogram of the spiked blank sample was free of interfering peaks and it showed a satisfactory overlay in terms of retention times with that of the standard solution. The recovery, LOD, and relative standard deviation (RSD) for water were as follows: LOD of target compounds (include IS) ranged from $5.0 \times 10^{-4}$ to $1.5 \times 10^{-2} \mathrm{ng} / \mathrm{ml}$ for water, and $3.0 \times 10^{-5}$ to $1.5 \times 10^{-2} \mathrm{ng} / \mathrm{g}$ for sediment. The recovery study performed on blank samples spiked with known levels $(0.1 \mu \mathrm{g} / \mathrm{l})$ of the OCPs is summarized in Table 1. Three replicates for each sample were carried out at three fortification levels $(0.05$, $0.10,0.50 \mu \mathrm{g} / \mathrm{l}$ for water and $0.5,5.0,50.0 \mu \mathrm{g} / \mathrm{kg}$ for sediments), and the relevant recovery results, given as mean values, were $72-103 \%$ and $71-103 \%$ for water and sediment, respectively. RSD was $2.0-7.0 \%$ and $4.0-8.0 \%$ for water and sediment, respectively. 2, 4, 5, 6-tetrachloro-m-xylene was used as an IS to assess the losses involved in the sample extraction and analysis.

All data were subject to strict quality control procedures including the repeatability of gas chromatography with electron capture detection (GC/ECD) determinations through the analysis of procedural blanks and spiked samples (100 ng/ g). Identification was accomplished using relative retention time techniques while quantification was done by comparison of peak areas of samples to those of standard solutions at known concentrations. Identification of those pesticides was confirmed on a number of samples with gas chromatographymass spectrometry (Agilent 6890 with mass spectrometer Agilent 5973 MSD (Agilent Technologies, USA)). A capillary column (HP- $35 \mathrm{~ms}, 30 \mathrm{~m} \times 0.25 \mathrm{~mm}$ i.d., and $0.25 \mu \mathrm{m}$ film thickness) was used. The oven temperature has been programmed as follows: $70^{\circ} \mathrm{C}$ for $2 \mathrm{~min}$, ramp at $25^{\circ} \mathrm{C} / \mathrm{min}$ to $150^{\circ} \mathrm{C}$ then, ramp at $3^{\circ} \mathrm{C} / \mathrm{min}$ to $200^{\circ} \mathrm{C}$. The final isotherm has been ramped at $8{ }^{\circ} \mathrm{C} / \mathrm{min}$ to $280^{\circ} \mathrm{C}$, hold for $10 \mathrm{~min}$. Injector temperature was $250^{\circ} \mathrm{C}$. The constant pressure was of $20 \mathrm{psi}$ and injection volume was of $2 \mu \mathrm{l}$. 


\section{Results and discussion}

\subsection{Physicochemical characteristics of sediment and water samples}

Table 2 provides the basic physicochemical parameters of sediment samples collected from the Guanting reservoir. The depth of water column above the sediment layer was between 8.5 and $1.2 \mathrm{~m}$. The water content of sediments ranged from $36.1 \%$ to $71.5 \%$. The organic matter (denoted by loss on ignition, LOI \%) of sediments ranged from $3.98 \%$ to $8.49 \%$. The maximum organic matter of the sediment samples was observed at the sampling site 7 which is located in front of a dam. Sediments with high organic carbon are more likely to adsorb lipophilic organochlorines than those with lower organic carbon levels. $\mathrm{pH}$ of sediments ranged from 7.91 to 8.52 with an average of 8.06 . The physicochemical properties of water samples were also analyzed. The range of $\mathrm{COD}_{\mathrm{Cr}}$ in water samples was between 3.5 and $18.5 \mathrm{mg} / \mathrm{l}$. The maximum value of $\mathrm{COD}_{\mathrm{Cr}}$ was at site 7 and the minimum was at site 3 . Clay and silt content (\%) denote the texture of sediment samples. The maximum value of sum of clay $\%$ and silt (\%) was the sample from site 7 (87.9\%).

\subsection{Levels and spatial distribution of OCPs in sediment and water}

Despite the ban and restriction on the usage of some OCPs, the analyzed samples showed the presence of OCPs in water and sediment at concentrations above the method of detection limits. OCPs detected in water and sediment include $p$, $p^{\prime}$-DDE, $p, p^{\prime}$-DDD, $p, p^{\prime}$-DDT, o, $p^{\prime}$-DDT, sum of $\alpha-, \beta-, \gamma$ - and $\delta$-HCH, HCB, heptachlor, HEPO, $\alpha$-chlordane, $\gamma$-chlordane, aldrin, endosulfans I, \& II, endosulfan sulfate, endrin aldehyde, endrin, diedrin and methoxychlor. The results of OCPs residues in sediment, pore water and water samples are shown in Table 3. Concentrations of total OCPs ranged from 5250 to $33,400 \mathrm{pg} / \mathrm{g} \mathrm{d.w}$. (dry weight) for sediment samples, from 275 to $1600 \mathrm{ng} / \mathrm{l}$ for pore water and from 16.7 to $791 \mathrm{ng} / \mathrm{l}$ for water samples, with a mean concentration of $234 \mathrm{ng} / \mathrm{l}$ in water, $644 \mathrm{ng} / \mathrm{l}$ in pore water, $13,000 \mathrm{pg} / \mathrm{g}$ in sediment. The results of OCPs residues in sediment samples from the studied sites were compared with OCPs concentrations (ng/g d.w.) in the sediments in rivers, lakes or estuaries from other locations in Asia (see Table 4).

The total DDT (sum of $p, p^{\prime}$-DDE, $p, p^{\prime}$-DDD, $p, p^{\prime}$-DDT and $o$, $p^{\prime}$-DDT) and $\gamma-\mathrm{HCH}$ in sediment samples were $3.25-17.2 \mathrm{ng} / \mathrm{g}$ d.w. and $0.0013-0.14 \mathrm{ng} / \mathrm{g}$ d.w., respectively. And levels of all detected pesticides were below the New York sediment quality criteria and guidelines to protect wildlife from adverse effect associated with bioaccumulation of persistent substance in aquatic biota (total DDT 100 and $\gamma-\mathrm{HCH} 1500 \mathrm{ng} / \mathrm{g}$ d.w.) (Mac Doanld, 1994). According to Chinese guideline GHZB3838-2002 (SEPA (State Environmental Protection Administration of China), 2002), in the grade 1-3 surface water, the concentration of $\gamma-\mathrm{HCH}$ should be less than $2000 \mathrm{ng} / \mathrm{l}$, DDTs should be less than $1000 \mathrm{ng} / \mathrm{l}$ (According to USEPA guideline, the critical value for DDT is $1000 \mathrm{ng} / \mathrm{l}$ too), HEPO should be less than $200 \mathrm{ng} / \mathrm{l}$. Concentrations of OCPs in water (Table 3) are generally lower than the Chinese standards for surface water. However, values in a few sites (site 1, site 5 and site 6) are considerably high for use as a drinking water. Mean residue levels of DDT were generally similar to that of $\mathrm{DDE}+\mathrm{DDD}$ congeners in water samples from the reservoir, but the ratio of $\mathrm{DDT} /(\mathrm{DDE}+\mathrm{DDD})$ was more than 1.0 in a few sampling locations of the reservoir, indicating recent possible sources (Wang et al., 2003; Sarkar et al., 1997). DDT residue levels were relatively higher than DDE congener in sediments from the reservoir. The DDT compounds in sediments may be mainly derived from DDT-treated aged and weathered agricultural sources. Generally, the most common isomers of $\mathrm{HCH}$ in the environment are $\alpha-\mathrm{HCH}, \beta-\mathrm{HCH}$ and $\gamma-\mathrm{HCH}$. But results in this study show that there were high concentrations of $\delta$ - $\mathrm{HCH}$ in sediments in a few sampling sites. Possible reasons that there were high concentrations of $\delta$ - $\mathrm{HCH}$ in sediments in the area are still unclear. Among the $\mathrm{HCH}$ isomers, $\alpha-\mathrm{HCH}$ is more likely to partition to the air and

\section{Table 2 - The basic physicochemical properties of natural surface sediment samples collected from Guanting reservoir}

\begin{tabular}{|c|c|c|c|c|c|c|c|}
\hline Sampling sites & $\begin{array}{l}\text { Site } \\
\text { description }\end{array}$ & $\begin{array}{c}\text { Water } \\
\text { depth } \\
(\mathrm{m})\end{array}$ & $\begin{array}{c}\text { Water } \\
\text { content } \\
(\%)\end{array}$ & $\begin{array}{l}\text { Loss on } \\
\text { ignition } \\
\text { (LOI, \%) }\end{array}$ & $\mathrm{pH}$ & Clay (\%) & Silt (\%) \\
\hline $\begin{array}{l}1\left(40^{\circ} 27^{\prime} 16^{\prime \prime} \mathrm{N},\right. \\
\left.115^{\circ} 59^{\prime} 34^{\prime \prime} \mathrm{E}\right)\end{array}$ & Yanqing & 1.2 & 40.0 & 7.13 & 7.97 & 24.8 & 52.1 \\
\hline $\begin{array}{l}2\left(40^{\circ} 21^{\prime} 41^{\prime \prime} \mathrm{N},\right. \\
\left.115^{\circ} 45^{\prime} 39^{\prime \prime} \mathrm{E}\right)\end{array}$ & Laohuailai & 5.5 & 42.8 & 4.58 & 8.12 & 18.5 & 37.7 \\
\hline $\begin{array}{l}3\left(40^{\circ} 16^{\prime} 51^{\prime \prime} \mathrm{N},\right. \\
\left.115^{\circ} 35^{\prime} 08^{\prime} \mathrm{E}\right)\end{array}$ & Erdaojian & 3.5 & 69.7 & 3.98 & 8.52 & 8.9 & 28.2 \\
\hline $\begin{array}{l}4\left(40^{\circ} 18^{\prime} 02^{\prime \prime} \mathrm{N},\right. \\
\left.115^{\circ} 37^{\prime} 37^{\prime \prime} \mathrm{E}\right)\end{array}$ & Yanghekou & 2.5 & 59.2 & 5.59 & 8.03 & 19.8 & 37.4 \\
\hline $\begin{array}{l}5\left(40^{\circ} 16^{\prime} 11^{\prime \prime} \mathrm{N},\right. \\
\left.115^{\circ} 20^{\prime} 10^{\prime \prime} \mathrm{E}\right)\end{array}$ & Baohaoqiao & 1.5 & 36.1 & 6.72 & 7.95 & 20.3 & 44.6 \\
\hline $\begin{array}{l}6\left(40^{\circ} 18^{\prime} 03^{\prime \prime} \mathrm{N},\right. \\
\left.115^{\circ} 36^{\prime} 58^{\prime \prime} \mathrm{E}\right)\end{array}$ & Baizhaihe & 5.8 & 64.8 & 6.81 & 7.92 & 21.4 & 39.8 \\
\hline $\begin{array}{l}7\left(40^{\circ} 15^{\prime} 07^{\prime \prime} \mathrm{N},\right. \\
\left.115^{\circ} 36^{\prime} 09^{\prime \prime} \mathrm{E}\right)\end{array}$ & Baqian & 8.5 & 71.5 & 8.49 & 7.91 & 30.4 & 57.5 \\
\hline
\end{tabular}




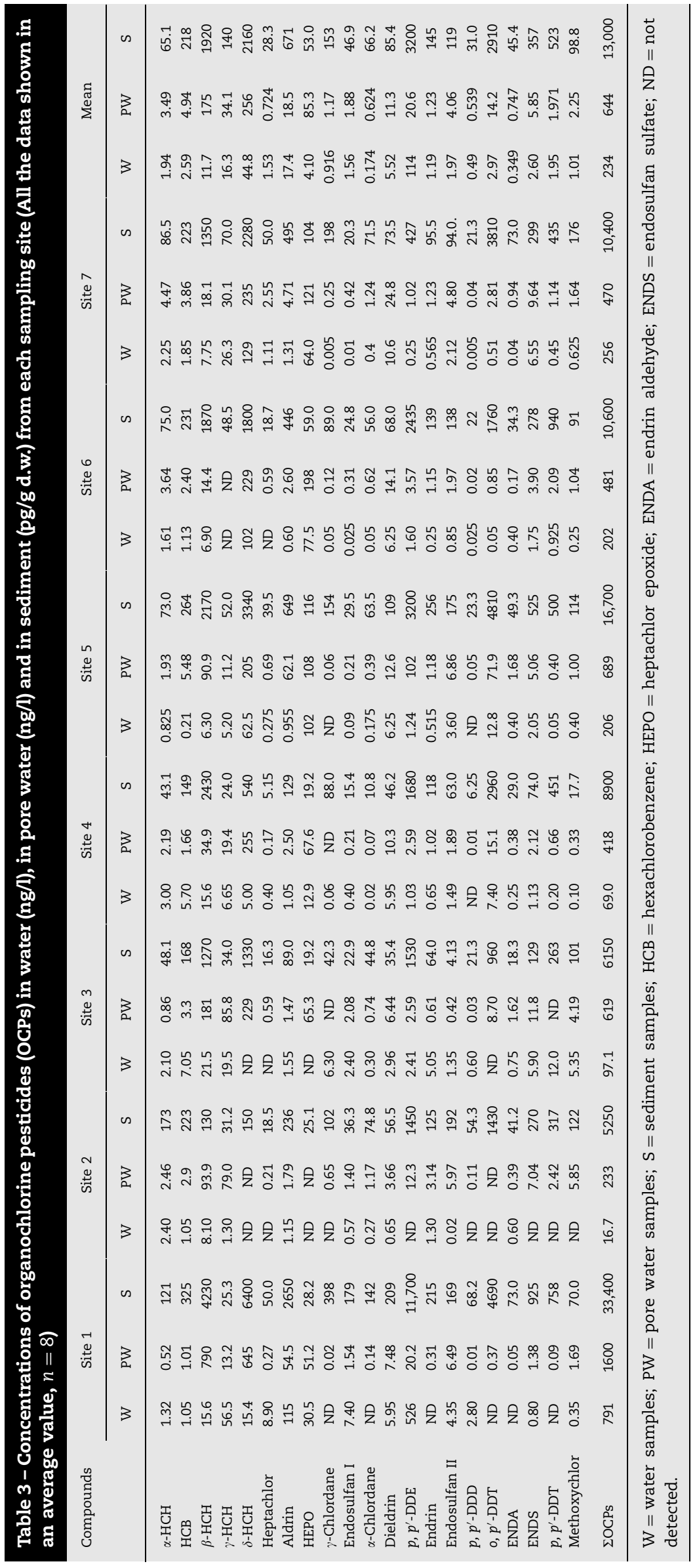


Table 4 - Comparison of organochlorine pesticides (OCPs) concentrations (ng/g d.w.) in the sediments in rivers, lakes or estuaries from other Asian locations

\begin{tabular}{|c|c|c|c|c|c|}
\hline Locations & Year & Total DDT & Chlordane & $\mathrm{HCHs}$ & References \\
\hline Northern Coast, Vietnam & 1998 & $6.2-10.4$ & $\mathrm{NA}^{\mathrm{a}}$ & $1.2-33.7$ & Nhan et al. (1999) \\
\hline Masan Bay, Korea & 1998 & $0.07-7.83$ & n.d. -0.18 & $0.01-0.59$ & Khim et al. (1999) \\
\hline $\begin{array}{l}\text { Yesilirmak river, Turkey (wet } \\
\text { wt) }\end{array}$ & 1998-2000 & 71 & NA & $14-16$ & Bakan and Ariman (2004) \\
\hline Hong Kong, China & 1997-1998 & $0.27-14.8$ & n.d. -11.3 & $0.1-16.7$ & $\begin{array}{l}\text { Richardson and Zheng } \\
\text { (1999) }\end{array}$ \\
\hline Wu-Shi estuary, Taiwan & 1997-1998 & n.d.-11.4 & $0.46-27.2$ & $0.99-14.5$ & Doong et al. (2002b) \\
\hline River/estuaries systems, China & 1996-1998 & $0.1-71$ & NA & $0.2-101$ & $\begin{array}{l}\text { Wu et al. (1999), Yuan et al. } \\
\text { (2001) }\end{array}$ \\
\hline $\begin{array}{l}\text { Beijing Guanting reservoir, } \\
\text { China }\end{array}$ & 2003-2004 & $3.25-17.2$ & $0.087-0.54$ & $0.28-10.8$ & This study \\
\hline
\end{tabular}

transport for a along distance. Since $\alpha-\mathrm{HCH}$ exhibits the most carcinogenic activity among $\mathrm{HCH}$ isomers, the contamination levels detected may pose a high ecotoxicity for aquatic organisms (Doong et al., 2002b). The frequency of detection of aldrin and HCB compounds in both sediment and water samples showed that the contamination of aldrin and HCB was widespread in Guanting reservoir. It has been reported that HCB is still being extensively produced in China against termites (Xu et al., 2004) and chlordane ( $\alpha$-chlordane and $\gamma$ chlordane) and aldrin are still being extensively used in China (Wu et al., 1997). However, the fact that concentrations of heptachlor, HEPO, dieldrin, endrin and endrin aldehyde exceed the detection limits of method in water and sediment samples from a few locations indicates that further investigation is needed to understand if there is long-range transport pathway for those pesticides into the area.

Figure 2 depicted the compositions of 21 OCPs residues from Guanting reservoir in surface water (A), pore water (B) and sediment $(C)$ samples. Figure 2 shows there were high concentrations of $\beta$-HCH, aldrin, $p, p^{\prime}$-DDE, o, $p^{\prime}$-DDT, endosulfan sulfate and $p, p^{\prime}$-DDT and low concentrations of $\alpha-\mathrm{HCH}$, heptachlor, endosulfan I, $\alpha$-chlordane, dieldrin, $p, p^{\prime}$-DDD, endrin aldehyde and methoxychlor whether in surface water, pore water or in sediment samples from the reservoir. $\mathrm{P}, \mathrm{p}^{\prime}$ DDE, $\delta$ - $\mathrm{HCH}$, aldrin, $\gamma$ - $\mathrm{HCH}$ and $\beta$-HCH composed of about $85 \%$ of total OCPs are the major OCPs in water while $p, p^{\prime}$-DDE, o, $p^{\prime}$-DDT, $\beta$-HCH, $\delta$-HCH, $p, p^{\prime}$-DDT and aldrin accounted for $85 \%$ of total OCPs in sediment and $\delta$ - $\mathrm{HCH}, \beta-\mathrm{HCH}$, heptachlor epoxide, $\gamma$-HCH, $p, p^{\prime}$-DDE and aldrin accounted for about $90 \%$ of total 21 OCPs in porewater. In comparison with results from the Tonghui River (Zhang et al., 2004) $\alpha-\mathrm{HCH}, \delta-\mathrm{HCH}$, heptachlor, endosulfan II, and total DDT are the major OCPs in water while heptachlor, dieldrin and DDE composed of $95 \%$ of total OCPs in sediment in the Tonghui River.

Among all sampling sites, high concentrations of OCPs were found in sediments from site 1 , site 5 , site 6 and site 7 . The data are in agreement with the results of $\mathrm{HCH}$ and DDT residues in Guanting reservoir (Wang et al., 2003). Considering the higher values of organic matter (LOI, \%), clay (\%) plus silt (\%) in site 1 , site 5 , site 6 , site 7 than in other sites, we can conclude that OCPs in the reservoir are significantly corre- lated ( $n=7, p<0.05)$ with some factors such as organic matter (LOI, \%), clay (\%) and silt (\%) $(r=0.48,0.42$ and 0.57, respectively). This was in agreement with the result (Sarkar et al., 1997) that the higher amounts of OCPs mainly occur in sediments with a high TOC and small grain size. Particularly organic matter, which influences microbial activities and variation, plays a most important role in accumulation, enrichment or degradation to pesticides. It may be due to the fact that organic hydrophobic pollutants tend to stay in the sediments (Zhang et al., 2004). Therefore, removal of sediments from the reservoir to decrease organic matter and clay content might be an effective measure to remediate the water polluted by OCPs.

\subsection{Variation in concentration and possible sources of OCPs in the reservoir}

The results showed that the concentration of pesticides in pore water was higher than those in surface water except $\gamma$ $\mathrm{HCH}, \gamma$-chlordane, $p, p^{\prime}$-DDE and endrin. High concentration of $\gamma$-HCH, $\gamma$-chlordane, $p, p^{\prime}$-DDE and endrin indicated these pesticides in surface water have other sources besides sediment.

The results showed that the concentration of pesticides in sediment was much higher than those in surface water. The concentration ratios (\%) of individual pesticides in surface water to those in sediment were generally lower than $10 \%$ with an exception of $\gamma-\mathrm{HCH}$. The results indicate a distribution pattern of pesticides in a water body though more studies need be done to understand why there are high ratios about $\gamma$ $\mathrm{HCH}$. However, the fact that the ratios (\%) of individual pesticide concentrations in surface water to those in pore water and in sediment were generally low suggested that sediment and pore water were potential sources of OCPs in surface water. This indicates that only a fraction of measured sediment OCPs concentrations was available to partition rapidly into aqueous samples, suggesting a rate-limited desorption of OCPs from the organic fraction of sediment. Therefore, the operation (such as unmanaged fish-farming, unrestricted shipping) in this reservoir will be a potential impact on leading to remobilization of sediment-bound OCPs. 


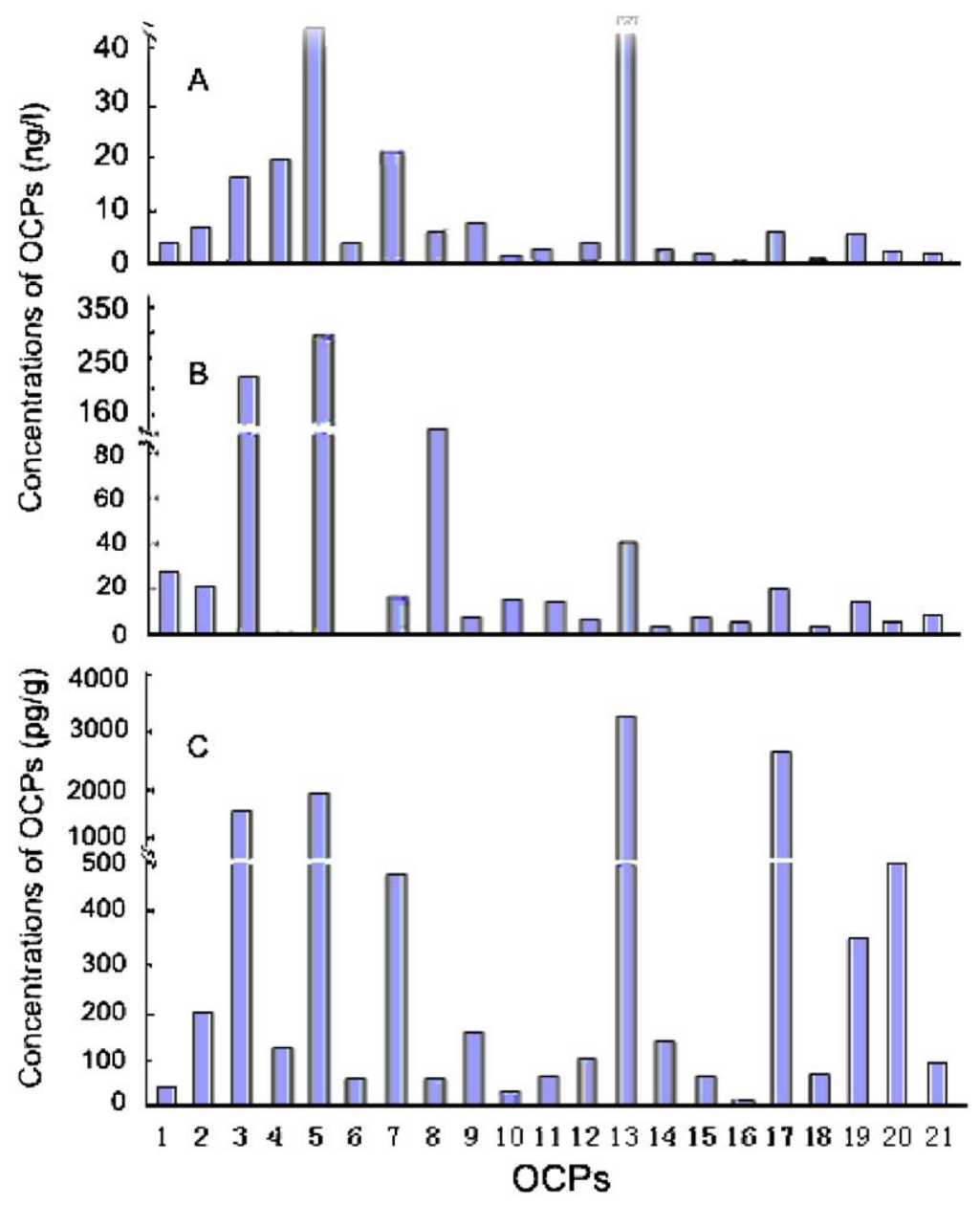

Fig. 2 - Compositions of organochlorine pesticide residues (OCPs) from Guanting reservoir in surface water (A), pore water (B) and sediment (C) samples (1, $\alpha-\mathrm{HCH} ; 2, \mathrm{HCB} ; 3, \beta-\mathrm{HCH} ; 4, \gamma-\mathrm{HCH} ; 5, \delta$-HCH; 6, heptachlor; 7, aldrin; 8, hepachlor epoxide; 9, $\gamma$-chlordane; 10, endosulfan I; 11, $\alpha$-chlordane; 12, dieldrin; 13, $p, p^{\prime}$-DDE; 14, endrin; 15, endosulfan II; 16, $p, p^{\prime}$-DDD; 17, o, $p^{\prime}$-DDT; 18, endrin aldehyde; 19, endosulfan sulfate; 20, p,p'-DDT; 21, methoxychlor).

The observed variation in concentration of pesticides in the reservoir (both in water and the sediments) can be expected to be caused by several reasons such as high rates of influx of contaminants into the reservoir through tributary rivers and drainage of contaminated water from the surrounding agricultural fields. The pollution might also be caused by the waste disposal from plants situated along rivers. Moreover, the diffusion of contaminants through the pores of the sedimentary layers influences the variation in concentration of various pesticides in sediment of different characteristics. Also, seasonal variation in microbial growth might influence the bio-irrigation of sediment resulting in an increase in mobility of various contaminants into the overlying water. In addition, another causative factor such as agricultural operations may cause relatively high concentration of pesticides in water.

\subsection{In situ sediment-pore water partition coefficients}

High concentrations in sediment relative to those in the water can result in predominant transfer of pesticides from the sediments through the benthic food-chain into organisms of higher trophic levels. The degree of sediment-water partitioning of a substance therefore plays a key role in the development of sediment quality criteria (Frank et al., 2003). Therefore it was possible to examine the relationship between sediment and pore water concentrations of OCPs. Several partitioning models have been developed by various researchers to understand the equilibrium partitioning and kinetic geochemistry of compounds in the environment (Gschwend and $\mathrm{Wu}$, 1985; Maruay et al., 1996; Khim et al., 2001). The equilibrium partitioning coefficient $\left(K_{\mathrm{oc}}\right)$ describes the relative affinity or attraction of the pesticide to sediment. Thus, $K_{\mathrm{oc}}$ values can be used when predicting the degree of sediment-water partitioning. Pesticides with smaller $K_{\mathrm{oc}}$ values likely have lower concentrations in sediment and relatively higher concentrations in pore water. To evaluate a partitioning behavior and fate of OCPs in Guanting reservoir, in situ sediment-pore water partition coefficient $\left(K_{\text {oc }}^{\prime}\right)$ was derived as

$K_{\text {OC }}^{\prime}=K_{\mathrm{p}}^{\prime} / f_{\text {oc }}$,

$K_{p}^{\prime}=C_{s} / C_{a q}$, 


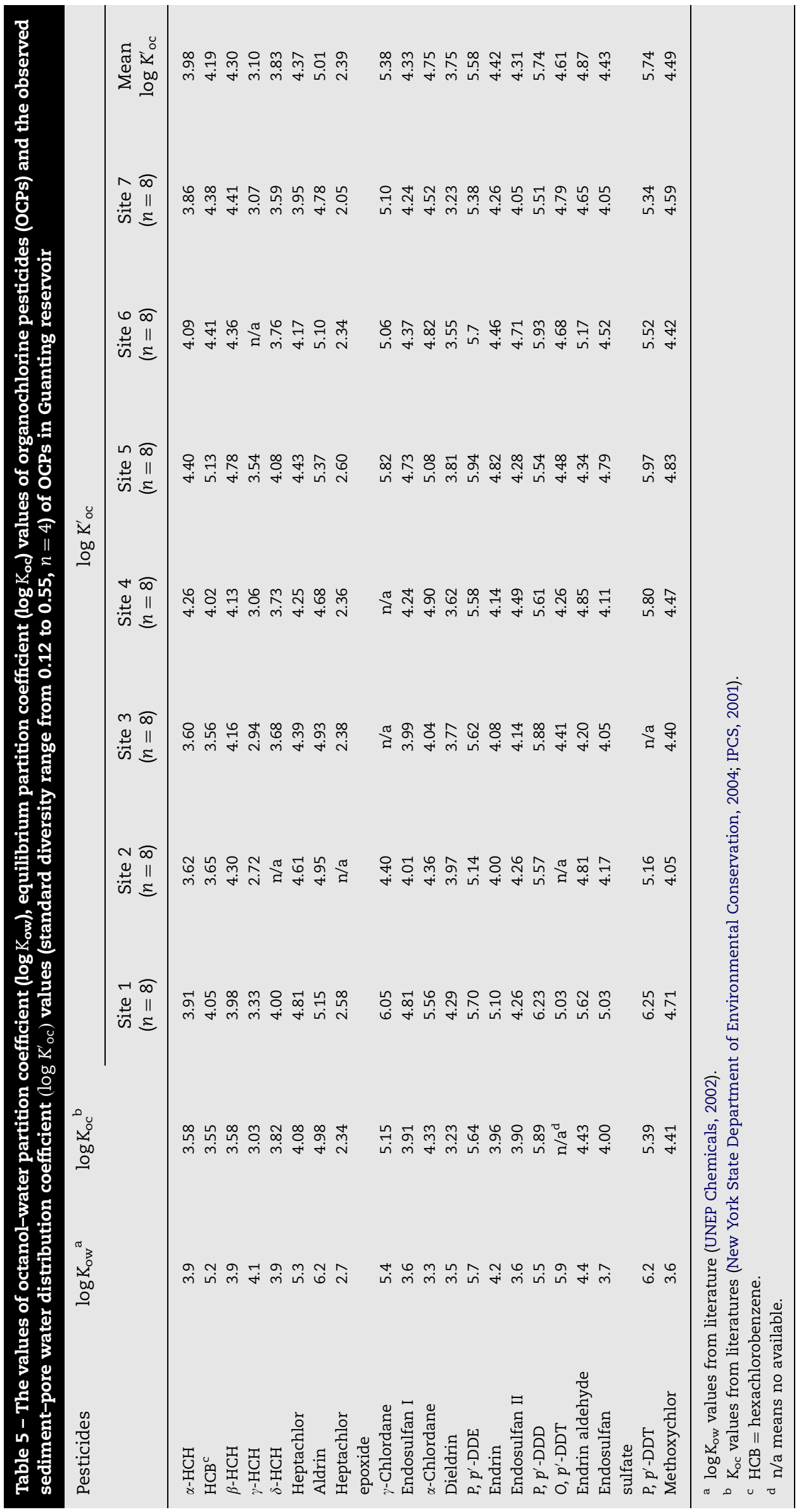


where $C_{\mathrm{s}}$ is the solid-phase concentration, $C_{\mathrm{aq}}$ is the aqueous phase concentration, and $f_{\text {oc }}$ is the sediment fractions of organic carbon (Maruay et al., 1996; Khim et al., 2001).

Values of $C_{\mathrm{s}}$ and $C_{\mathrm{aq}}$ for OCPs were detectable in sediment samples in Guanting reservoir. Values of $f_{\text {oc }}$ were estimated according to the equation for the weighted regression between LOI (\%) and organic carbon (Ball, 1964; Cambardella et al., 2001) as follows:

Organic carbon content $(\%)=0.458 \times$ LOI $(\%)-0.4$.

The $K_{p}^{\prime}$ and $K_{\text {oc }}^{\prime}$ for OCPs can be therefore calculated. Table 5 showed the values of octanol-water partition coefficient $\left(\log K_{\text {ow }}\right)$, sediment-pore water equilibrium partitioning coefficient $\left(\log K_{\mathrm{oc}}\right)$ and in situ sediment-pore water distribution coefficient ( $\log K^{\prime}{ }_{\text {oc }}$ ) values of OCPs in Guanting reservoir.

The $\log K_{\text {ow }}$ indicates how a chemical is distributed at equilibrium between organic (octanol) and aqueous (water) phases. This coefficient can be used in predicting the environmental fate of organic chemicals such as pesticides. The higher the $\log K_{\text {ow }}$, the greater the propensity for the chemical to be partitioned to organic phases is Fig. 3(A) showed the linear correlations between $\log K_{\text {ow }}$ and mean in situ log $K^{\prime}{ }_{\text {oc }}$ of OCPs within each sampling sites in Guanting reservoir $\left(R^{2}=0.5166, n=21, p<0.05\right)$. This indicates that the degree of disequilibrium between sediment and water increases when $\log K_{\text {ow }}$ drops (Frank et al., 2003). An estimate to the degree of sediment-water partitioning of OCPs can therefore be achieved by values of $\log K_{\text {ow }}$ to evaluate the behavior and fate of OCPs in Guanting reservoir. Values of $\log K_{\text {oc }}^{\prime}$ were generally in the same order of magnitude as literature values of $\log K_{\text {ow }}$ or $\log K_{\text {oc }}$. Fig. $3(B)$ showed the linear correlations between $\log K_{\text {oc }}^{\prime}$ and $\log K_{\mathrm{oc}}$ values $\left(R^{2}=0.791, n=20, p<0.05\right)$. And values of the in situ $\log K^{\prime}{ }_{\text {oc }}$ were generally greater than the corresponding $\log K_{\text {oc }}$ (see Table 5) indicating a disequilibrium between the measured sediment and pore water concentrations occurred. A possible explanation is that there was the exchange between the pore water and overlaying water column. The result is in agreement with studies on other hydrophobic and lipophilicorganic pollutants such as polynuclear aromatic hydrocarbons (PAHs) from San Francisco Bay (Maruay et al., 1996) and from Boston Harbor (Mcgroddy and Farrington, 1995), polychlorinated biphenyl (PCB) from Green Bay of lake Michgan (Frank et al., 2003). The result also indicates that only a fraction of total measured sediment OCPs concentrations was available to come to equilibrium with the surrounding pore waters (Maruay et al., 1996). A larger discrepancy of values between in situ $\log K_{\text {oc }}^{\prime}$ and the corresponding $\log K_{\mathrm{oc}}$ indicates more disequilibrium degree between measured sediment and pore water concentrations.

Among all sampling sites, larger discrepancy of values between in situ $\log K_{\text {oc }}^{\prime}$ and the corresponding $\log K_{\mathrm{oc}}$ were found at site 1 (on a tributary of the reservoir near YanQing town), and site 5 (on a tributary through the agricultural region) than in other sampling sites. Sites 1 and 5 are situated in tributaries where water flows faster, then, more pesticide exchange occur between the pore water and overlaying water column than in other sites in Guanting reservoir. The pore water concentrations were depleted by the exchange with surface water relative to the pore water concentrations
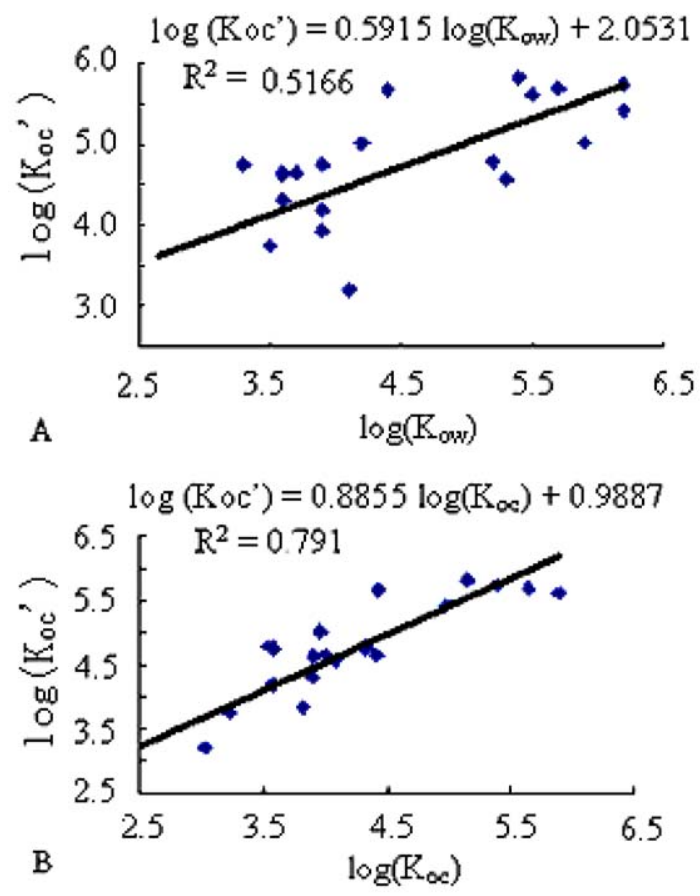

Fig. 3 - The linear correlations between observed distribution coefficients ( $\log K_{\text {oc }}^{\prime}$ ) of organochlorine (OCPs) sediment-pore water in Guanting reservoir and octanol-water partition coefficient $\left(\log K_{\text {ow }}\right)$ values $(n=21, p<0.05)(A)$ and the linear correlations between observed distribution coefficients ( $\log K^{\prime}{ }_{\text {oc }}$ ) of organochlorine (OCPs) sediment-pore water in Guanting reservoir and equilibrium partitioning coefficient $\left(\log K_{o c}\right)$ values $(n=20, p<0.05)$ (B).

predicted by equilibrium partitioning coefficients. An apparent disequilibrium between the measured sediment and pore water concentrations was observed and the tendency of OCPs diffusion from sediments to surface water was predicted. Considering the high concentrations of OCPs in sediments from sites 1 and 5 (see Section 3.2), a risk of OCPs contamination to surface water can occur in the two sites due to the diffusion of OCPs from sediments.

\section{Conclusions}

A multiresidue analysis method based on GC was developed for the analysis of OCPs in water and surface sediment.

The analyses showed the concentrations of OCPs in water from Guanting reservoir are generally lower than the Chinese standards (in the grade 1-3 surface water), after the usage was banned or restricted for 20 years in the area. However, values in a few sites are considerably high relative to standards for water supply.

OCPs in Guanting reservoir were mainly caused from several pathways such as contaminants through the rivers and drainage of contaminated water from the surrounding agricultural fields or plants, the diffusion from sediment 
through the pores. Organic matter, which influences microbial activities and variation, play a most important role in accumulation, enrichment or degradation to OCPs in Guanting reservoir. The concentration of OCPs in sediment was much higher than those in surface water. Higher values of in situ $\log K_{\text {oc }}^{\prime}$ were found from sites 1 and 5 than in other sampling sites imply that a likely diffusion of OCPs from sediments in the two locations.

Among the analyzed OCPs, $p, p^{\prime}$-DDE, $\delta$ - $\mathrm{HCH}$, aldrin, $\gamma-\mathrm{HCH}$ and $\beta-\mathrm{HCH}$ were the most abundant compounds in water while $p, p^{\prime}$-DDE, o, $p^{\prime}$-DDT, $\beta$-HCH, $\delta$-HCH, $p, p^{\prime}$-DDT and aldrin accounted for $85 \%$ of total 21 OCPs in sediment.

These results underscore the need to improve environmental protection measures in order to reduce the exposure of the population and aquatic biota to these persistent and bioaccumulative compounds. Furthermore, regular monitoring is needed to evolve a strategy to manage the environmental hazards due to these OCPs. Further measures, such as restricting shipping and managing fish-farming, need be taken to decrease OCPs in order to remediate the water pollution for municipal water supply source.

\section{Acknowledgements}

The study was supported by Ministry of Science and Technology, China (2003CB415005). The authors wish to thank Mr. Zhe Cao and Dr. Ping Li from Agilent Technologies, Beijing Environment Lab. for helping with mass spectrometric confirmations. The authors wish to thank Dr. Rongbiao Zhao and Dr. Zhao Rusong, Dr. Xuetong Wang, Dr. Yangzhao Sun, for the help of sampling on site.

R E F E R E N C E S

Bakan, G., Ariman, S., 2004. Persistent organochlorine residues in sediments along the coast of mid-Black Sea region of Turkey. Mar. Pollut. Bull. 48, 1031-1039.

Ball, D.F., 1964. Loss-on-ignition as an estimate of organic matter and organic carbon in non-calcareous soils. J. Soil Sci. 15 (1), 84-92.

Cambardella, C.A., Gajda, A.M., Doran, J.W., Wienhold, B.J., Kettler, T.A., 2001. Estimation of particulate and total organic matter by weight loss-on-ignition. In: Lal, R., et al. (Eds.), Assessment Methods for Soil Carbon. Advances in Soil Science. CRC Press, Boca Raton, FL, pp. 349-359.

Chau, A.S.Y., Afgan, B.K., 1982. Analysis of Pesticides in Water, vol. 1: Significance, Principles, Techniques and Chemistry of Pesticides, vol. 2: Chlorine and Phosphorus-Containing Pesticides. CRC Press Inc., Boca Raton, FL, pp. 91-238.

Colborn, T., Smolen, M.J., 1996. Epidemiological analysis of persistent organochlorine contaminations in cetaceans. Rev. Environ. Contam. Toxicol. 146, 91-172.

Doong, R.A., Sun, Y.C., Liao, P.L., Peng, C.K., Wu, S.C., 2002a. Distribution and fate of organo-chlorine pesticide residues in sediments from the selected rivers in Taiwan. Chemosphere 48, 237-246.

Doong, R.A., Peng, C.K., Sun, Y.C., Liao, P.L., 2002b. Composition and distribution of organochlorine pesticide residues in surface sediments from the Wu-Shi River Estuary, Taiwan. Mar. Pollut. Bull. 45, 246-253.
Fillmann, G., Readman, J.W., Tolosa, I., Bartocci, J., Villeneuve, J.P., Cattini, C., Mee, L.D., 2002. Persistent organochlorine residues in sediments from Black Sea. Mar. Pollut. Bull. 44, 122-133.

Frank, A., Gobas, P.C., Maclean, L.G., 2003. Sediment-water distribution of organic contaminants in aquatic ecosystems: the role of organic carbon mineralization. Environ. Sci. Technol. 37, 35-741.

Golterman, H.L., Sly, P.G., Thomas, R.L., 1983. Study on the relationship between water quality and sediment transport. Technical Papers in Hydrology 26, UNESCO, France.

Gschwend, P.M., Wu, S., 1985. On the constancy of sedimentwater partition coefficients of hydrophobic organic pollutants. Environ. Sci. Technol. 19, 90-96.

Hakanson, L., Jansson, M., 1983. Principles of Lake Sedimentology. Springer, New York.

Hong, H., Chen, W., Xu, L., Wang, Z., Zhang, L., 1999. Distribution and fate of organochlorine pollutants in the Pearl River Estuary. Mar. Pollut. Bull. 39, 376-382.

IPCS (The International Programme on Chemical Safety). 2001. The framework of the Inter-Organization Programme for the Sound Management of Chemicals (IOMC). Website: www.bluegreenearth.us/archive/reviews

Iwata, H., Tanabe, S., Sakai, N., Nishimura, A., Tatsukawa, R., 1994. Geographical distributions of persistent organochlorines in air, water and sediments from Asia and Oceania and their implications for global redistribution from low latitudes. Environ. Pollut. 85, 15-33.

Khan, M.A.Q., 1977. Pesticides in Aquatic Environment. Plenum Press, New York.

Khim, J.S., Kannan, K., Villeneuve, D.L., Kon, C.H., Giesy, J.P., 1999. Characterization and distribution of trace organic contaminants in sediment from Masan Bay, Korea. 1. Instrumental analysis. Environ. Sci. Technol. 33, 4199-4205.

Khim, J.S., Lee, K.T., Kannan, K., Villeneuve, D.L., Giesy, J.P., Koh, C.H., 2001. Trace organic contaminants in sediment and water from Ulsan Bay and its vicinity. Korean Arch. Environ. Contam. Toxicol. 40, 141-150.

Mac Doanld, D.D., 1994. A review of environmental quality criteria and guidelines for priority substances in the Fraser River Basin. Mac Donald Environmental Science Limited, Environmental Conservation Branch, Canada.

Maruay, K.A., Risebrough, R.W., Horne, A.J., 1996. Partitioning of polynuclear aromatic hydrocarbons between sediments from San Francisco Bay and their porewaters. Environ. Sci. Technol. 30, 2942-2947.

Mcgroddy, S.E., Farrington, J.W., 1995. Sediment pore water partitioning of polycyclic aromatic hydrocarbons in three cores from Boston Harbor, Massachusetts. Environ. Sci. Technol. 29, 1542-1550.

Monirith, I., Ueno, D., Takahashi, S., Nakata, H., Sudaryanto, A., Subramanian, A., Karuppiah, S., Ismail, A., Muchtar, M., Zheng, J., Richardson, B.J., Prudente, M., Hue, N.D., Tana, T.S., Tkalin, A.V., Tanabe, S., 2003. Asia-Pacific mussel watch: monitoring contamination of persistent organochlorine compounds in coastal waters of Asian countries. Mar. Pollut. Bull. 46, 281-300.

New York State Department of Environmental Conservation, 2004. Organic pesticides/herbicides and PCBs soil cleanup criteria table. Website: www.dec.state.ny.us/website/der/ tagms

Nhan, D.D., Am, N.M., Carvalho, F.P., Vieneuve, J.P., Cattini, C., 1999. Organochlorine pesticides and PCBs along the coast of north Vietnam. Sci. Total Environ. 237/238, 363-371.

Nogueira, J.M.F., Sandra, T., Sandra, P., 2004. Multiresidue screening of neutral pesticides in water samples by high performance liquid chromatography-electrospray mass spectrometry. Anal. Chim. Acta 505 (2), 209-215. 
Richardson, B.J., Zheng, G.J., 1999. Chlorinated hydrocarbon contaminants in Hong Kong surficial sediments. Chemosphere 39, 913-923.

Robert, E.C. (Ed.), 1971. Procedures in Sedimentary Petrology. Wiley-Interscience, New York A division of John Wiley and Sons, pp. 69-92 (Chapter 4).

Sarkar, A., Nagarajan, R., Chaphadkar, S., Pal, S., Singbal, S.Y.S., 1997. Contamination of organochlorine pesticides in sediments from the Arabian Sea along the west coast of India. Water Res. 31 (2), 195-200.

SEPA (State Environmental Protection Administration of China), 2002. Environmental quality standard for surface water (GHZB3838-2002).

Tanabe, S., Iwata, H., Tatsukawa, R., 1994. Global contamination by persistent organochlorines and their ecotoxicological impact on marine mammals. Sci. Total Environ. 154, 163-177.

Tanabe, S., Madhusree, B., Ozt.urk, A.A., Tatsukawa, R., Myazaka, N., Ozdamar, E., Aral, O., Samsun, O., 1997. Persistent organochlorine residues in Harbour Porpoise (Phocoena phocoena) from the Black Sea. Mar. Pollut. Bull. 34, 338-347.

UNEP Chemicals, 2002. Regional reports of the regionally based assessment of persistent toxic substances program. Website: www.chem.unep.ch/pts

Wang, X.T., Chu, S.G., Xu, X.B., 2003. Organochlorine pesticide residues in water from Guanting Reservoir and Yongding River, China. Bull. Environ. Contam. Toxicol. 70, 351-358.
Wania, F., Mackay, D., 1996. Tracking the distribution of persistent organic pollutants. Environ. Sci. Technol. 30, 390A-396A.

Wu, W.Z., Schramm, K.W., Henkelmann, B., Xu, Y., Yediler, A., Kettrup, A., 1997. PCDD/Fs, PCBs, HCHs and PCBs in sediments and soils of Ya-Er Lake area in China: results on residue levels and correlation to the organic carbon and the particle size. Chemosphere 34, 191-202.

Wu, Y., Zhang, J., Zhou, Q., 1999. Persistent organochlorine residues in sediments from Chinese river/estuary systems. Environ. Pollut. 105, 143-150.

Xu, D., Zhong, W., Deng, L., Chai, Z., Mao, X., 2004. Regional distribution of organochlorinated pesticides in pine needles and its indication for socioeconomic development. Chemosphere 54, 743-752.

Xue, N., Wang, H., Xu, X., 2005. Progress in study on endocrine disrupting pesticides (EDPs) in aquatic environment. Chin. Sci. Bull. 50 (20), 2257-2266.

Yuan, D., Yang, D., Wade, T.L., Qian, Y., 2001. Status of persistent organic pollutants in the sediments from several estuaries in China. Environ. Pollut. 114, 101-111.

Zhang, Z., Huang, J., Yu, G., Hong, H., 2004. Occurrence of PAHs, PCBs and organochlorine pesticides in the Tonghui River of Beijing, China. Environ. Pollut. 130, 249-261.

Zhou, J.L., Maskaoui, K., Qui, Y.W., Hong, H.S., Wang, Z.D., 2001. Polychlorinated biphenyl congeners and organochlorine insecticides in the water column and sediments of Daya Bay, China. Environ. Pollut. 113, 373-384. 